\title{
Persistent Organochlorine Pesticide Residues in Water, Sediments and Fish Samples from Ogbese River
}

\author{
Olayinka A. Ibigbami ${ }^{1,2}$, Ademola F. Aiyesanmi ${ }^{2}$, Emmanuel I. Adeyeye ${ }^{1} \&$ Albert O. Adebayo $^{2}$ \\ ${ }^{1}$ Department of Chemistry, Ekiti State University, PMB 5363, Ado- Ekiti, Nigeria \\ ${ }^{2}$ Department of Chemistry, The Federal University of Technology, PMB 704, Akure, Nigeria \\ Correspondence: Olayinka A. Ibigbami, Department of Chemistry, Ekiti State University, PMB 5363, Ado- Ekiti, \\ Nigeria. Tel: 234-806-418-2009. E-mail: olayinkaibigbami@yahoo.co.uk
}

\author{
Received: May 18, 2015 Accepted: May 31, 2015 Online Published: July 22, 2015 \\ doi:10.5539/enrr.v5n3p28 URL: http://dx.doi.org/10.5539/enrr.v5n3p28
}

\begin{abstract}
This study considered the levels of 15 organochlorine pesticide (OCPs) residues ( $\alpha$-BHC, $\beta$ - BHC, $\Upsilon$-BHC, lindane, chlorothalonil, heptachlor, aldrin, heptachlor epoxide, endosulfan I, endosulfan II, endrin, dieldrin, $\mathrm{p}$, p'-DDD, p, p'-DDT and endosulfan sulphate in water, sediments and fish species from Ogbese river in Ekiti State, Southwestern Nigeria. Samples were extracted and cleaned-up on silica gel adsorbent. The OCPs concentrations were determined using Gas chromatograph (GC) equipped with Electron Capture Detector. The OCPs concentration in water and sediments ranged from below detection limit (BDL): BDL $-13.6 \mu \mathrm{g} / \mathrm{L}$ and $0.52-450$ $\mu \mathrm{g} / \mathrm{kg}$ whilst the mean OCPs in the fish ranged from $2.64-66.0 \mu \mathrm{g} / \mathrm{kg}$, respectively. The results indicated that all the analysed fish samples were contaminated with the studied pesticides. Endosulfan I was found to be above EU and FAO/WHO maximum residue limits (MRL) in Clarias gariepinus fish samples. The sediments and fish samples showed evidence of organochlorine pesticides enrichment and bioaccumulation. Chi-square at $\alpha=0.05$ showed there were significant differences in the levels of organochlorine pesticide residues in sediments and fish samples except $\alpha$-BHC.
\end{abstract}

Keywords: organochlorine pesticide (OCPs), detection limit, gas chromatograph (GC), bioaccumulation

\section{Introduction}

The organochlorine pesticides (OCPs) in this study [aldrin, endrin, dieldrin, chlordane, heptachlor, DDT, toxaphene, mirex and hexachlorobenzene (HCB)] constitute nine out of the twelve chemical substances defined under the Stockholm Convention on persistent organic pollutants (POPs). These compounds are characterised by high persistent, low polarity, low aqueous solubility and high lipid solubility (lipophilicity). They are ecotoxic, non-biodegrable and able to bioaccumulate and biomagnify in living organisms (Lars, 2000; Afful et al., 2010). In 2009, the Stockholm Convention, at its fourth meeting, listed additional chemicals as persistent organic pollutant (POPs), among which are five pesticides: chlordecone, alpha hexachlorocyclohexane $(\alpha-\mathrm{HCH})$, beta hexachlorocyclohexane $(\beta-\mathrm{HCH})$, gamma hexachlorocyclohexane (lindane) and pentachlorobenzene. Of these five additional chemicals, one (lindane) was also investigated in this research. The toxicity of OCPs has caused them to be banned in developed and many developing nations. Even so, some developing countries still use them (Ennacer et al., 2008; Adeyemi et al., 2011). Besides their persistence in the environment, organochlorine contaminants move considerable long distances and get accumulated in vegetation, soil and water bodies of high latitude by the global distillation phenomenon, particularly in Polar Regions (Simonich \& Hites, 1995; Nizzetto et al., 2008). In Nigeria, there have been reports of some levels of pesticide residues in water, sediments and fish (Ajayi \& Osibanjo, 1981; Osibanjo \&Bamgbose, 1990; Ize- Iyamu et al., 2007; Ogunfowokan et al., 2012; Idowu et al., 2013). The results have continually revealed contamination by OCPs in Nigeria rivers. Several activities (such as waste from industrial chemical production, pesticides runoff from agricultural areas, sewage and refuse dump) have contributed to the levels of chlorinated hydrocarbon compounds in Nigerian rivers. Because of their potency, efficiency and low cost compared with alternative pesticides, OCPs are still being used by some cocoa farmers (Akinnifesi et al., 2006; Idowu et al., 2013). The use of OCPs such as DDT has been outlawed since 1990 in Nigeria. Meeting the minimum requirements of health standards is generally regarded as one of the elements of sustainable agricultural development. 
In Nigeria, Federal Environmental Protection Agency FEPA (1991) has established criteria, guidelines, specifications and standards for pesticides usage. FEPA standard for maximum allowable limits for water is $0.1 \mathrm{mg} / \mathrm{L}$. It is therefore necessary to conduct regular monitoring of pesticide residues and their stable metabolites to ascertain if their concentrations meet the prescribed limits as established by Nigeria government. In cocoa production in Nigeria particularly in the south-west we have two major cocoa cropping seasons: the major cropping season falls usually in the rainy season and the light cropping season in the dry season. Many pesticides are used during the major cocoa cropping season because of high humidity that supports the growth of phytophthora, a disease of cocoa pods predominates during the rains. Residues of these pesticides used on the cocoa farms, and possibly other agricultural areas, are washed into the rivers when rain falls. These compounds being hydrophobic can potentially bioaccumulate in the fatty tissues of fish and as a result of feeding habits of the fish, may lead to biomagnification in human beings eating the fish (Afful et al., 2010). This research aims to determine the extent of contamination of Ogbese river by organochlorine pesticides (OCPs) residues.

\section{Materials and Methods}

\subsection{Study Area}

Figure 1 shows the study area. The Ogbese river is one of the major rivers in south-western Nigeria particularly in Ekiti State where the study was carried out. It has many tributaries. The river cut across three states in Nigeria: Ondo, Ekiti and Kogi. The river plays important roles in the socio-economic development of the people living beside and near it, such as fishing, farming (irrigation) and washing. Ekiti State, where the samples were collected, lies between latitude $7^{0} 40^{1} \mathrm{~N}$ and longitude $5^{0} 15^{1} \mathrm{E}$ on the western part of Nigeria. Ekiti State covers about $6,353 \mathrm{~km}^{2}$ land area. The state is mainly an upland zone rising over $250 \mathrm{~m}$ above sea level. It lies in an area underlained by metamorphic rock and dotted with rugged hills. Its vegetation is rainforest with characteristic tall trees and grasses.

\subsection{Sample Collection and Preservation}

Samples of water, sediments and fish were collected from the river. Water samples were taken at five different locations along the course of the river by grab method. At each sampling location four grab samples were taken across the width of the river and pulled together to form a composite sample. The sample was then stored in a pre-cleaned glass bottle. The water samples were acidified by concentrated $\mathrm{HNO}_{3}$ to $\mathrm{pH} 2$ to prevent alteration of the organic matter. The samples were kept in glass bottle and preserved in a refrigerator prior to analysis.

Sediments samples were taken at five different locations as in the case of water samples using pre-cleaned Ekman grab sampler. The sample was taken into a glass bottle, labeled as represented. The sediment samples were air-dried, sieved through $2 \mathrm{~mm}$ mesh and stored in black polythene bags prior subsequent analysis. Three fish samples were collected for each specie. The fish samples were caught from the river using drag net method. The fish samples were wrapped in aluminium foil and stored in a deep freezer prior to analysis. The fish samples were identified at the Fisheries and Aquaculture Department, Ekiti State University, Ado-Ekiti.

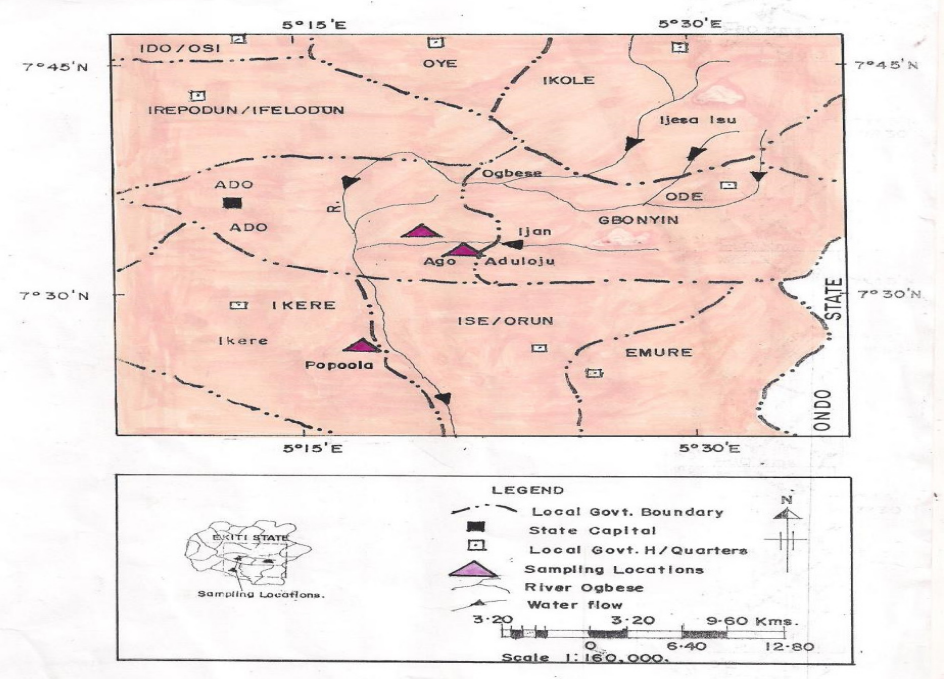

Figure 1. The study area within Ekiti State showing the sampling locations 


\subsection{Chemical Analysis}

\subsubsection{Extraction of OCPs from Water Sample}

Method 3510 as described by US EPA 2007 was used to extract the pesticide residues in the water samples. $50 \mathrm{ml}$ of dichloromethane (DCM) was introduced into the separating funnel containing $100 \mathrm{ml}$ of the sample and shaken vigorously for about 2 minutes. The sample was allowed to settle for 30 minutes to ensure separation of the phases. After separation, the organic layer was filtered into a $250 \mathrm{ml}$ conical flask through anhydrous sodium sulphate $\left(\mathrm{Na}_{2} \mathrm{SO}_{4}\right)$ that has been prewashed with DCM. The extractions were repeated twice using a $50 \mathrm{ml}$ portion of dichloromethane and later combined. The combined organic extracts were concentrated using a rotary evaporator at $45^{\circ} \mathrm{C}$ and low pressure. $5 \mathrm{ml}$ of $\mathrm{n}$-hexane was added to the extract in DCM to exchange the solvent. The extracts were further concentrated to $1-2 \mathrm{ml}$ using a rotary evaporator at $45^{\circ} \mathrm{C}$ until no further DCM remained in the extract. The extracts were transferred into $2 \mathrm{ml} \mathrm{GC}$ vials before analysis with Gas Chromatography.

\subsubsection{Extraction of OCPs from Sediment and Fish Samples}

Extraction of OCPs in sediment and fish samples was carried out by the EPA 3550C method described by USEPA (2000) with slight modification to the weights of the samples. For the sediment, $20 \mathrm{~g}$ of each sample and $20 \mathrm{~g}$ of anhydrous $\mathrm{Na}_{2} \mathrm{SO}_{4}$ was added. $50 \mathrm{ml}$ mixture of acetone and $\mathrm{n}$-hexane $(1: 1 \mathrm{v} / \mathrm{v})$ were then mixed with the sample in a $100 \mathrm{ml}$ volumetric flask. This was followed by sonication in a high frequency ultra-sonic bath for 10-15 minutes at about $60^{\circ} \mathrm{C}$. The extract was then decanted into a round bottom flask. The extraction process was reapeated with additional $50 \mathrm{ml}$ (acetone and $\mathrm{n}$-hexane), sonicated and allowed to settle and decant into the same round bottom flask. The extracts was concentrated using a rotary evaporator to $1-2 \mathrm{ml}$. The extract was re-dissolved in $5 \mathrm{ml} \mathrm{n}$-hexane and later concentrated to $2 \mathrm{ml}$ in a rotary evaporator at $40^{\circ} \mathrm{C}$. Fish samples were prepared by the method described by Afful et al. (2010). About $10 \mathrm{~g}$ each of properly homogenised head and muscle tissue of fish samples were separately placed in a beaker containing $25 \mathrm{~g}$ of anhydrous sodium sulphate $\left(\mathrm{Na}_{2} \mathrm{SO}_{4}\right)$ and mixed thoroughly. Acetone: $\mathrm{n}$-hexane $(1: 1 \mathrm{v} / \mathrm{v})$ of $40 \mathrm{ml}$ were added and the mixtures were sonicated for 15 minutes. The extracts were filtered into a round bottom flask. The extraction process was reapeated with additional $40 \mathrm{ml}$ (acetone and $\mathrm{n}$-hexane), sonicated and allowed to settle and filtered into the same round bottom flask. The extract was concentrated to $2 \mathrm{ml}$ using a rotary evaporator. The extract was re-dissolved in $5 \mathrm{ml} \mathrm{n}$-hexane and later concentrated to $2 \mathrm{ml}$ in a rotary evaporator at $40^{\circ} \mathrm{C}$. This was later cleaned up using activated silica gel.

\subsubsection{Extract Clean-up}

Sediment and fish samples were cleaned-up using activated silica gel. The column of about $15 \mathrm{~cm}$ (length) $\mathrm{X}$ $1 \mathrm{~cm}$ (internal diameter) was packed with $2 \mathrm{~g}$ of deactivated silica gel and $1 \mathrm{~g}$ anhydrous $\mathrm{Na}_{2} \mathrm{SO}_{4}$ packed on top of the silica gel (adsorbent). The columns were each conditioned with $15 \mathrm{ml}$-hexane prior to clean-up. The extract was introduced into the column and eluted with $20 \mathrm{ml}$ of $\mathrm{n}$-hexane and diethyl ether $(1: 1 \mathrm{v} / \mathrm{v})$. The eluate was concentrated to dryness on the rotary evaporator and recovered into $2 \mathrm{ml} \mathrm{n}$-hexane. The extracts were transferred into glass $\mathrm{GC}$ vials for $\mathrm{GC}$ analysis using electron capture detector (ECD).

\subsubsection{Bioconcentration Factor (BCF) and Enrichment Factor (EF)}

In order to evaluate the $\mathrm{BCF}$ in the fish, the residual OCPs concentration in the fish was divided by the residual concentration of OCPs in related water respectively. The enrichment factor (EF) was estimated as a ratio between the concentration of OCPs in the sediments and water respectively.

\subsubsection{Gas Chromatographic Analysis}

A gas chromatography model Agilent 7890A equipped with electron capture detector (ECD) was used. The carrier gas nitrogen flow rate was $4.0 \mathrm{ml} / \mathrm{min}$. The temperature of injector was held at $250^{\circ} \mathrm{C}$, oven temperature was at $250^{\circ} \mathrm{C}$ and electron capture detector was set at $300^{\circ} \mathrm{C}$ respectively. The oven temperature was programmed at $80^{\circ} \mathrm{C}$ for 1 minute, ramped to $180^{\circ} \mathrm{C}$ at $10^{\circ} \mathrm{C} / \mathrm{min}$ (held for 3 minutes) and to $300^{\circ} \mathrm{C}$ at $10^{\circ} \mathrm{C} / \mathrm{min}$ (held for 2 minutes). The total run time was 28 minutes. The column type is HP5 MS (30 m X $0.25 \mu \mathrm{m}$ and $0.32 \mathrm{~mm}$ ).

\subsection{Quality Assurance and Quality Control}

Laboratory blank samples were extracted and analysed on a regular basis. The retention times for standard samples were used for confirmation of the pesticides. Retention time windows were constant for the standard samples and were therefore relied upon for component identification. Calibration curves were produced with four different standard concentrations. The calibration lines showed excellent linearity in the range of the concentrations of interest. To determine the quality of the methodology, a recovery study was performed using 
standard addition methods. Four samples were spiked with the mixture of pesticides standards. The spiked samples were extracted and analysed as described in the method above. The results revealed that the mean recovery values ranged from 83.3 to $98.7 \%$. This indicates that the analytical procedures outlined for the OCPs determination in this study were reliable, reproducible and efficient.

\section{Results and Discussion}

Table 1 showed the results of the various OCPs residues in water samples from the studied area. As may be seen, $\alpha$ - BHC, endosulfan I and endrin were below the detection limit (BDL) $(0.15 \mu \mathrm{g} / \mathrm{L})$ in all the water samples. The OCPs concentration level in the water samples ranged from BDL $-13.6 \mu \mathrm{g} / \mathrm{L}$ for $\beta$-BHC, lindane (BDL - 3.15 $\mu \mathrm{g} / \mathrm{L}$ ), $\Upsilon$ - BHC (1.14 - $3.89 \mu \mathrm{g} / \mathrm{L}$ ), chlorothalonil (BDL - $0.52 \mu \mathrm{g} / \mathrm{L}$ ), heptachlor (BDL - $0.35 \mu \mathrm{g} / \mathrm{L}$ ), aldrin (BDL - $0.85 \mu \mathrm{g} / \mathrm{L}$ ), heptachlor epoxide (1.30 - $5.75 \mu \mathrm{g} / \mathrm{L}$ ), dieldrin (BDL - $0.23 \mu \mathrm{g} / \mathrm{L}$ ), endosulfan II (BDL - $6.17 \mu \mathrm{g} / \mathrm{L}$ ), p, p'-DDD (BDL -1.39 $\mu \mathrm{g} / \mathrm{L})$, endosulfan sulphate $(3.01-10.9 \mu \mathrm{g} / \mathrm{L})$ and $\mathrm{p}$, p'-DDT $(0.61-3.04 \mu \mathrm{g} / \mathrm{L})$. The mean OCPs concentration levels in the water were: $\beta$ - BHC $(7.45 \pm 4.99 \mu \mathrm{g} / \mathrm{L})>$ endosulfan sulphate $(6.28+$ $3.10 \mu \mathrm{g} / \mathrm{L})>$ endosulfan II $(4.45 \pm 1.89 \mu \mathrm{g} / \mathrm{L})>$ heptachlor epoxide $(2.73 \pm 1.95 \mu \mathrm{g} / \mathrm{L})>\Upsilon$ - BHC $(2.08 \pm 1.08$ $\mu \mathrm{g} / \mathrm{L})>$ lindane $(2.03 \pm 2.33 \mu \mathrm{g} / \mathrm{L})>\mathrm{p}, \mathrm{p}^{\prime}-$ DDT $(1.80 \pm 1.15 \mu \mathrm{g} / \mathrm{L})>\mathrm{p}, \mathrm{p}^{\prime}-$ DDD $(1.12 \pm 0.263 \mu \mathrm{g} / \mathrm{L})>$ aldrin $(0.559 \pm 0.361 \mu \mathrm{g} / \mathrm{L})>$ chlorothalonil $(0.269 \pm 0.36 \mu \mathrm{g} / \mathrm{L})$. The results indicated higher concentrations of organochlorine pesticide residues in the water samples when compared with previous results from the same river in the Ondo State axis (Idowu et al., 2013; Okoya et al., 2013). According to Okoya et al. (2013), sixteen OCPs residues $(\mathrm{HCB}, \alpha$-BHC, $\beta$ - BHC, $\Upsilon$-BHC, heptachlor, aldrin, trans-chlordane, cis-chlordane, $\alpha$-endosulfan, $\beta$-endosulfan, $\mathrm{p}, \mathrm{p}^{\prime}-\mathrm{DDE}, \mathrm{o}, \mathrm{p}^{\prime}-\mathrm{DDD}, \mathrm{p}, \mathrm{p}^{\prime}-\mathrm{DDD}, \mathrm{p}, \mathrm{p}^{\prime}-\mathrm{DDT}$, dieldrin and endrin) were not detected in Ogbese river. Previous and current use of the pesticides, run-off from various agricultural areas, washing of materials or containers after pesticide application, environmental factors, nature and fate of pesticides in an aquatic environment could all have contributed to the current levels of the OCPs in the river. The concentration of aldrin and $\mathrm{p}, \mathrm{p}^{\prime}-\mathrm{DDT}$ were higher than dieldrin and $\mathrm{p}, \mathrm{p}^{\prime}-\mathrm{DDD}$, which were their metabolites. The presence of dieldrin and $\mathrm{p}, \mathrm{p}^{\prime}-\mathrm{DDD}$ in the water body resulted from transformation of aldrin and $\mathrm{p}, \mathrm{p}^{\prime}-\mathrm{DDT}$. DDT metabolizes very slowly to DDD and DDE in human beings and is excreted from the body in the urine. Sunlight and bacteria could change aldrin to dieldrin which in soil and water degrades slowly (ATSDR, 2002).

The residue level of heptachlor epoxide in most cases was higher than heptachlor while the concentration of lindane in the water samples in this study was within the range reported for the river Ovia in Edo State (Ize-Iyamu et al., 2007). The contamination of the river might be connected with the use of lindane used by farmers in the area.

Table 1. Concentration ( $\mu \mathrm{g} / \mathrm{L}$ ) of organochlorine pesticide residues in water samples from Ogbese river

\begin{tabular}{|c|c|c|c|c|c|c|c|c|c|c|c|c|c|c|c|c|}
\hline $\begin{array}{l}\text { Sample } \\
\text { code }\end{array}$ & $\alpha-\mathrm{BHC}$ & $\beta$-BHC & Lindane & $\Upsilon$-BHC & $\begin{array}{l}\text { Chloro } \\
\text { thalonil }\end{array}$ & Heptachlor & Aldrin & $\begin{array}{c}\text { Heptachlor } \\
\text { Epoxide }\end{array}$ & $\begin{array}{c}\text { Endosulfan } \\
\text { I }\end{array}$ & Dieldrin & Endrin & $\begin{array}{c}\text { Endosulfan } \\
\text { II }\end{array}$ & $\mathrm{P}, \mathrm{P}^{\mathrm{I}}-\mathrm{DDD}$ & $\begin{array}{c}\text { Endosulfan } \\
\text { sulphate }\end{array}$ & $\mathrm{P}, \mathrm{P}^{\mathrm{I}}$-DDT & TOCP \\
\hline OGS 1 & BDL & BDL & 0.91 & 1.14 & BDL & BDL & BDL & 1.31 & BDL & $\mathrm{BDL}$ & BDL & BDL & BDL & 3.01 & 0.61 & 6.98 \\
\hline OGS 2 & $\mathrm{BDL}$ & 13.6 & BDL & 2.19 & 0.52 & BDL & 0.85 & 3.67 & BDL & 0.23 & $\mathrm{BDL}$ & 6.17 & 1.11 & 10.9 & 3.04 & 42.3 \\
\hline OGS 3 & BDL & 6.34 & BDL & 1.49 & 0.15 & BDL & 0.16 & 1.64 & BDL & BDL & BDL & 1.86 & BDL & 4.09 & 1.81 & 17.5 \\
\hline OGS 4 & BDL & 8.31 & 3.15 & 1.67 & BDL & 0.35 & 0.67 & 5.75 & BDL & BDL & BDL & 4.31 & 0.86 & 7.47 & 1.63 & 33.8 \\
\hline OGS 5 & $\mathrm{BDL}$ & 1.54 & BDL & 3.89 & BDL & BDL & BDL & 1.3 & BDL & BDL & $\mathrm{BDL}$ & 5.45 & 1.39 & 5.91 & 2.53 & 22 \\
\hline$\Sigma \mathrm{OCP}$ & BDL & 29.8 & 4.06 & 10.4 & 0.67 & 0.35 & 1.68 & 13.7 & BDL & 0.23 & BDL & 17.8 & 3.36 & 28.4 & 9.62 & 123 \\
\hline \multirow[t]{2}{*}{ Range } & - & BDL- & BDL- & $1.14-$ & BDL- & BDL- & BDL- & $1.3-$ & $\mathrm{BDL}$ & BDL- & BDL & BDL- & BDL- & $3.01-$ & $0.61-$ & $6.98-$ \\
\hline & & 13.6 & 3.15 & 3.89 & 0.52 & 0.35 & 0.85 & 5.75 & & 0.23 & & 6.17 & 1.39 & 10.9 & 3.04 & 42.3 \\
\hline Mean & - & 7.45 & 2.03 & 2.08 & 0.27 & - & 0.56 & 2.73 & - & - & - & 4.45 & 1.12 & 6.28 & 1.8 & 366 \\
\hline SD & - & 4.99 & 110 & 1.08 & 0.36 & - & 0.36 & 1.95 & - & - & - & 1.89 & 0.26 & 3.1 & 1.15 & 245 \\
\hline $\mathrm{CV} \%$ & - & 66.9 & 1.23 & 51.9 & 134 & - & 64.4 & 71.4 & - & - & - & 42.5 & 23.2 & 49.4 & 63.9 & 66.9 \\
\hline $\mathrm{X} 2$ & - & 10 & 1.23 & 2.6 & 0.48 & - & 0.46 & 7.88 & - & - & - & 2.39 & 0.12 & 6.1 & 2.95 & 659 \\
\hline Remark & - & $\mathrm{S}$ & NS & NS & NS & - & NS & $\mathrm{S}$ & - & - & - & NS & NS & NS & NS & $\mathrm{S}$ \\
\hline
\end{tabular}

$\mathrm{BDL}=$ Below detection limit $<0.15 \mu \mathrm{g} / \mathrm{L} ;$ OGS $=$ Ogbese; $\mathrm{SD}=$ Standard deviation; $\mathrm{CV}=$ Coefficient variation; $\mathrm{NS}=$ Not Significant; $\mathrm{S}=$ Significant; $\mathrm{TOCP}=$ Total organochlorine pesticide; $\Sigma \mathrm{OCP}=\mathrm{Sum}$ of organochlorine pesticide; $\mathrm{X}^{2}=$ Chi-square. 
Table 2. Concentration $(\mu \mathrm{g} / \mathrm{kg}$ ) of organochlorine pesticide residues in sediment samples from Ogbese river

\begin{tabular}{|c|c|c|c|c|c|c|c|c|c|c|c|c|c|c|c|c|}
\hline $\begin{array}{l}\text { Sample } \\
\text { code }\end{array}$ & $\begin{array}{c}\alpha- \\
\mathrm{BHC}\end{array}$ & $\begin{array}{c}\beta- \\
\text { BHC }\end{array}$ & Lindane & $\begin{array}{c}\mathrm{Y}- \\
\mathrm{BHC}\end{array}$ & $\begin{array}{l}\text { Chloro } \\
\text { thalonil }\end{array}$ & Heptachlor & Aldrin & $\begin{array}{c}\text { Heptachlor } \\
\text { epoxide }\end{array}$ & $\begin{array}{c}\text { Endosulfan } \\
\text { I }\end{array}$ & Dieldrin & Endrin & $\begin{array}{c}\text { Endosulfan } \\
\text { II }\end{array}$ & $\mathrm{P}, \mathrm{P}^{\mathrm{I}}-\mathrm{DDD}$ & $\begin{array}{c}\text { Endosulfan } \\
\text { sulphate }\end{array}$ & $\begin{array}{l}{\mathrm{P}, \mathrm{P}^{1}-}_{-} \\
\text {DDT }\end{array}$ & TOCP \\
\hline OGS 1 & 13.9 & 450 & 48.7 & 106 & 151 & 139 & 75.3 & 60.5 & 131 & 30.7 & 75.6 & 43.9 & 33.0 & 63.6 & 16.9 & 1439 \\
\hline OGS 2 & 28.2 & 73.5 & 32.6 & 78.4 & 110 & 102 & 56.4 & 43.0 & 103 & 25.9 & 57.7 & 37.9 & 28.6 & 23.4 & 15.2 & 816 \\
\hline OGS 3 & 57.9 & 254 & 61.0 & 17.3 & 211 & 212 & 111 & 86.4 & 199 & 107 & 92.1 & 69.4 & 54.2 & 38.9 & 23.5 & 1957 \\
\hline OGS 4 & 2.03 & 85.2 & 9.62 & 13.1 & 37.5 & 31.9 & 18.2 & 16.7 & 50.1 & 22.4 & 34.5 & 20.4 & 12.2 & 12.9 & 3.75 & 371 \\
\hline OGS 5 & 1.30 & 63.3 & 6.43 & 12.7 & 24.1 & 20.8 & 10.9 & 10.0 & 25.6 & 3.30 & 12.7 & 8.35 & 4.58 & 4.69 & 0.52 & 211 \\
\hline$\sum \mathrm{OCP}$ & 103 & 926 & 158 & 227 & 534 & 506 & 272 & 217 & 509 & 189 & 273 & 180 & 133 & 143 & 59.9 & 4430 \\
\hline \multirow[t]{2}{*}{ Range } & $1.30-$ & 63.3- & $6.43-$ & $12.7-$ & $24.1-$ & $20.8-$ & $10.9-$ & $10.0-$ & $25.6-$ & $3.30-$ & $12.7-$ & $8.35-$ & $4.58-$ & 4.69- & $0.52-$ & $211-$ \\
\hline & 57.9 & 450 & 61.0 & 106 & 211 & 212 & 111 & 86.4 & 199 & 107 & 92.1 & 69.4 & 54.2 & 63.6 & 23.5 & 2310 \\
\hline Mean & 20.7 & 185 & 31.7 & 45.5 & 107 & 101 & 54.4 & 43.3 & 102 & 37.9 & 54.5 & 36.0 & 26.5 & 28.7 & 12.0 & 1133 \\
\hline SD & 23.5 & 167 & 23.8 & 43.8 & 78.2 & 79.0 & 41.4 & 31.5 & 68.5 & 40.0 & 31.7 & 23.4 & 19.4 & 23.3 & 9.57 & 948 \\
\hline $\mathrm{CV} \%$ & 114 & 90.3 & 75.1 & 96.3 & 73.1 & 78.2 & 76.1 & 72.7 & 67.2 & 106 & 58.2 & 65.0 & 73.2 & 81.2 & 79.8 & 83.7 \\
\hline $\mathrm{X} 2$ & 107 & 606 & 71.8 & 169 & 229 & 247 & 126 & 91.6 & 184 & 169 & 73.2 & 60.7 & 56.5 & 75.8 & 30.5 & 3173 \\
\hline Remark & $\mathrm{S}$ & $\mathrm{S}$ & $\mathrm{S}$ & $\mathrm{S}$ & $\mathrm{S}$ & $\mathrm{S}$ & S & $\mathrm{S}$ & $\mathrm{S}$ & $\mathrm{S}$ & $\mathrm{S}$ & $\mathrm{S}$ & $\mathrm{S}$ & $\mathrm{S}$ & $\mathrm{S}$ & $\mathrm{S}$ \\
\hline
\end{tabular}

$\mathrm{BDL}=$ Below detection limit $<0.15 \mu \mathrm{g} / \mathrm{kg}$; OGS $=$ Ogbese; $\mathrm{SD}=$ Standard deviation; $\mathrm{CV}=$ Coefficient of variation; $\mathrm{NS}=$ Not Significant; $\mathrm{S}=$ Significant; $\mathrm{TOCP}=$ Total organochlorine pesticide; $\Sigma \mathrm{OCP}=\mathrm{Sum}$ of organochlorine pesticide; $\mathrm{X}^{2}=$ Chi-square.

The mean concentration of OCPs obtained for the water samples were within the same range reported by Ogunfowokan et al. (2012); but the results obtained were higher than those reported for other rivers in Nigeria (Ize-Iyamu et al., 2007; Okoya et al., 2013). The results showed that the mean concentration level of 10 out of the 15 pesticide residues detected in the water samples were above the maximum acceptable concentration of 0.1 $\mu \mathrm{g} / \mathrm{L}$ value set by the European Union for the protection of the aquatic environment and drinking water, whilst the levels were very low when compared to the FEPA allowable level of $10 \mu \mathrm{g} / \mathrm{L}$. Statistical results using chi-sqaure at $\alpha=0.05$ showed that there were significant differences in the levels of $\beta$-BHC whilst lindane, $\Upsilon$-BHC, chlorothalonil, aldrin, heptachlor epoxide, endosulfan II, p, $\mathrm{p}^{\prime}-\mathrm{DDD}$, endosulfan sulphate and $\mathrm{p}, \mathrm{p}^{1}$ -DDT showed no significant differences in the levels of OCPs in the river.

Table 2 showed the concentration of organochlorine pesticide residues in sediment samples. From all the pesticide residues determined, $\beta$-BHC, chlorothalonil, heptachlor and endosulfan I showed high concentrations when compared with other OCPs present in the sediment samples. The mean concentration of OCPs in the sediment ranged from $\mathrm{p}$, p'-DDT $(12.0 \pm 9.57 \mu \mathrm{g} / \mathrm{kg})$ to $\beta$ - BHC $(185 \pm 167 \mu \mathrm{g} / \mathrm{kg})$. The mean concentration of all the OCPs analysed in the sediment were: p, p'-DDT $(12.0 \pm 9.57 \mu \mathrm{g} / \mathrm{kg})<\alpha-$ BHC $(20.7 \pm 23.5 \mu \mathrm{g} / \mathrm{kg})<\mathrm{p}$, p'-DDD $(26.5 \pm 19.4 \mu \mathrm{g} / \mathrm{kg})<$ endosulfan sulphate $(28.7 \pm 23.3 \mu \mathrm{g} / \mathrm{kg})<$ lindane $(31.7 \pm 23.8 \mu \mathrm{g} / \mathrm{kg})<$ endosulfan II $(36.0 \pm 23.4 \mu \mathrm{g} / \mathrm{kg})<$ dieldrin $(37.9 \pm 40.0 \mu \mathrm{g} / \mathrm{kg})<$ heptachlor epoxide $(43.3 \pm 31.5 \mu \mathrm{g} / \mathrm{kg})<\Upsilon$ BHC $(45.5 \pm 43.8 \mu \mathrm{g} / \mathrm{kg})<$ aldrin $(54.4 \pm 41.4 \mu \mathrm{g} / \mathrm{kg})<$ endrin $(54.5 \pm 31.7 \mu \mathrm{g} / \mathrm{kg})<$ heptachlor $(101 \pm 79.0$ $\mu \mathrm{g} / \mathrm{kg})<$ endosulfan I $(102 \pm 68.5 \mu \mathrm{g} / \mathrm{kg})<$ chlorothalonil $(107 \pm 78 . \overline{2} \mu \mathrm{g} / \mathrm{kg})<\beta-$ BHC $(185 \pm 167 \overline{\mu g} / \mathrm{kg})$. Concentrations of the OCPs in water samples were much lower when compared to concentrations in sediment samples. This showed that the OCPs molecules were sparingly soluble in water (hydrophobic) and may therefore adsorb on the sediment particles of the river. Statistical results using chi-square showed that there were significant differences in each analyte in all the sediment samples. The results in Table 2 also showed higher concentration of p, p'-DDD than the parent p, p'-DDT in all the sediment samples. Aldrin and endosulfan were higher than their metabolites (dieldrin and endosulfan sulhphate) in the sediments. Looking at the ratio of the mean concentration of $\mathrm{p}, \mathrm{p}^{\prime}-\mathrm{DDD}$ to its parent compound $\mathrm{p}, \mathrm{p}^{\prime}-\mathrm{DDT}$ in the sediment samples, the results indicated less recent exposure to new sources of DDT and accumulation was probably through indirect use such as long range transport or historical application (Hong et al., 1999; Zhang et al., 1999; Adeyemi et al., 2011). The results in this study showed higher levels of OCPs compared with what was previously reported by Raposo jr et al. (2007) from water bodies in Culturama Brazil and Shukla et al. (2006) in Hyderabad city in India; whilst the Okavango delta in Botswana showed similar ranges in some instances as reported by Mmualafe et al. (2009). 
Low levels of these pesticides could result from the nature of the degradation of the pesticides, and the nature or amount of the pesticides as such, whether through runoff or direct application, among others.

Table 3. Mean distribution of organochlorine pesticide $(\mu \mathrm{g} / \mathrm{kg})$ residues in fish parts from Ogbese river

\begin{tabular}{|c|c|c|c|c|c|c|c|c|c|c|c|c|c|c|c|c|}
\hline $\begin{array}{l}\text { Sample } \\
\text { code }\end{array}$ & \multirow{2}{*}{$\begin{array}{c}\alpha-\mathrm{BHC} \\
5.66\end{array}$} & \multirow{2}{*}{$\begin{array}{r}\beta-\mathrm{BHC} \\
54.0\end{array}$} & \multirow{2}{*}{$\begin{array}{c}\text { Lindane } \\
5.31\end{array}$} & \multirow{2}{*}{$\begin{array}{r}\text { Y-BHC } \\
14.7\end{array}$} & \multirow{2}{*}{ 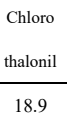 } & \multirow{2}{*}{$\begin{array}{c}\text { Heptachlor } \\
17.0\end{array}$} & \multirow{2}{*}{$\begin{array}{c}\text { Aldrin } \\
7.62\end{array}$} & \multirow{2}{*}{$\begin{array}{c}\begin{array}{c}\text { Heptachlor } \\
\text { epoxide }\end{array} \\
9.37\end{array}$} & \multirow{2}{*}{$\begin{array}{c}\text { Endosulfan } \\
\text { I } \\
24.7\end{array}$} & \multirow{2}{*}{$\begin{array}{c}\text { Dieldrin } \\
13.4\end{array}$} & \multirow{2}{*}{$\begin{array}{r}\text { Endrin } \\
16.1\end{array}$} & \multirow{2}{*}{$\begin{array}{c}\text { Endosulfan } \\
\text { II } \\
9.89\end{array}$} & \multirow{2}{*}{$\begin{array}{c}{\mathrm{P}, \mathrm{P}^{\mathrm{I}}-\mathrm{DDD}}^{-} \\
6.88\end{array}$} & \multirow{2}{*}{$\begin{array}{c}\begin{array}{c}\text { Endosulfan } \\
\text { sulphate }\end{array} \\
10.8\end{array}$} & \multirow{2}{*}{$\frac{P^{P, P^{1}-D D T}}{}$} & \multirow{2}{*}{$\begin{array}{r}\text { TOCP } \\
218\end{array}$} \\
\hline CG Head & & & & & & & & & & & & & & & & \\
\hline trunk & 16.0 & 38.1 & 22.5 & 63.1 & 69.9 & 67.6 & 34.7 & 44.9 & 107 & 66.5 & 79.2 & 50.8 & 37.4 & 49.9 & 16.4 & 764 \\
\hline CN Head & 6.28 & 52.4 & 5.32 & 15.1 & 16.7 & 15.9 & 10.3 & 11.8 & 29.1 & 18.4 & 30.3 & 16.7 & 10.9 & 14.4 & 8.16 & 262 \\
\hline Trunk & 4.52 & 14.9 & 7.85 & 21.0 & 24.6 & 22.4 & 14.6 & 14.8 & 38.7 & 23.0 & 32.1 & 20.2 & 12.4 & 21.9 & 8.38 & 281 \\
\hline TZ Head & 13.4 & 17.1 & 4.69 & 19.2 & 37.6 & 46.9 & 6.56 & 4.13 & 16.9 & 11.4 & 4.86 & 4.69 & 1.45 & 15.2 & 2.07 & 206 \\
\hline Trunk & 2.46 & 10.3 & 4.41 & 14.1 & 16.0 & 14.7 & 8.79 & 9.36 & 24.5 & 14.2 & 20.1 & 13.1 & 7.49 & 9.81 & 2.63 & 172 \\
\hline ON Head & 8.24 & 8.22 & 6.58 & 15.4 & 3.31 & 3.79 & 3.40 & 5.13 & 30.6 & 10.9 & 49.1 & 7.97 & 4.49 & 2.82 & 2.67 & 118 \\
\hline Trunk & 0.94 & 5.19 & 2.17 & 7.94 & 8.71 & 7.71 & 28.3 & 5.09 & 11.6 & 9.58 & 25.9 & 8.33 & 3.68 & 7.20 & 2.68 & 135 \\
\hline HN Head & 13.6 & 16.1 & 1.42 & 2.58 & 5.33 & 8.00 & 7.07 & 1.15 & 4.89 & 13.3 & 9.37 & 1.64 & 5.39 & 4.08 & 4.06 & 97.9 \\
\hline Trunk & 2.97 & 14.2 & 3.13 & 8.50 & 11.6 & 10.1 & 5.97 & 4.23 & 13.1 & 7.50 & 8.45 & 5.91 & 3.08 & 5.07 & 1.51 & 105 \\
\hline
\end{tabular}

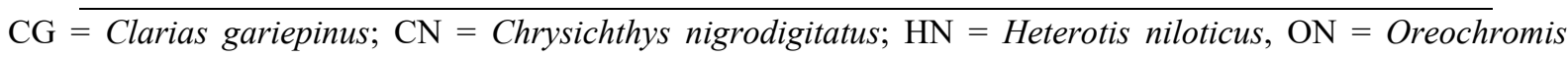
niloticus; TZ = Tilapia zilli.

Table 4. Mean concentration $(\mu \mathrm{g} / \mathrm{kg})$ of organochlorine pesticide residues in whole fish samples from Ogbese river

\begin{tabular}{|c|c|c|c|c|c|c|c|c|c|c|c|c|c|c|c|c|}
\hline $\begin{array}{l}\text { Sample } \\
\text { code }\end{array}$ & $\alpha-\mathrm{BHC}$ & $\beta-\mathrm{BHC}$ & Lindane & $\Upsilon$-BHC & $\begin{array}{l}\text { Chloro } \\
\text { thalonil }\end{array}$ & Heptachlor & Aldrin & $\begin{array}{c}\text { Heptachlor } \\
\text { epoxide }\end{array}$ & $\begin{array}{c}\text { Endosulfan } \\
\text { I }\end{array}$ & Dieldrin & Endrin & $\begin{array}{c}\text { Endosulfan } \\
\text { II }\end{array}$ & $\mathrm{P}, \mathrm{P}^{\mathrm{I}}-\mathrm{DDD}$ & $\begin{array}{l}\text { Endosulfan } \\
\text { sulphate }\end{array}$ & P,P ${ }^{1}-D D T$ & TOCP \\
\hline CG & 10.8 & 46.1 & 13.9 & 44.4 & 38.9 & 42.3 & 21.2 & 27.1 & 66.0 & 38.5 & 47.7 & 30.3 & 22.1 & 30.3 & 10.2 & 490 \\
\hline $\mathrm{CN}$ & 5.40 & 33.7 & 6.10 & 20.1 & 18.2 & 19.1 & 12.5 & 13.3 & 33.9 & 20.7 & 31.2 & 18.4 & 11.6 & 18.2 & 8.30 & 360 \\
\hline $\mathrm{TZ}$ & 8.01 & 13.7 & $4 . .51$ & 26.8 & 16.6 & 30.8 & 7.70 & 6.70 & 20.7 & 12.8 & 12.5 & 8.90 & 4.52 & 12.5 & 2.35 & 237 \\
\hline ON & 4.60 & 6.70 & 4.37 & 6.01 & 11.6 & 5.30 & 15.8 & 5.10 & 21.1 & 10.3 & 15.4 & 8.21 & 4.13 & 5.00 & 2.71 & 159 \\
\hline $\mathrm{HN}$ & 8.80 & 15.2 & 2.23 & 8.50 & 5.30 & 9.01 & 6.50 & 2.64 & 8.54 & 10.4 & 8.54 & 7.55 & 4.23 & 4.53 & 2.60 & 139 \\
\hline MRL & - & - & 20 & - & - & 200 & 200 & 200 & 50 & 200 & 50 & 50 & 300 & - & 300 & - \\
\hline
\end{tabular}

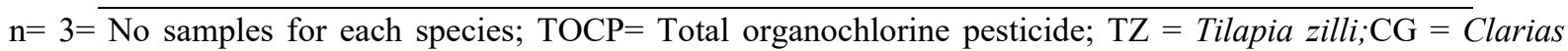
gariepinus; $\mathrm{CN}=$ Chrysichthys nigrodigitatus; $\mathrm{HN}=$ Heterotis niloticus; $\mathrm{ON}=$ Oreochromis niloticus; $\mathrm{MRL}=$ all the MRLs were obtained from (a) FAO/WHO Food Standards, Codex alimentarius, Maximum Residue Limits of Pesticides in food; (b)Pesticide EU-MRLs, Regulation (EC) NO 396/2005, updated on 02/12/2009.

Table 5. Bioconcentration factor (BCF) of organochlorine pesticide residues in fish samples in relation to fish and water

\begin{tabular}{|c|c|c|c|c|c|c|c|c|c|c|c|c|c|c|c|c|}
\hline $\begin{array}{c}\text { Sample } \\
\text { code }\end{array}$ & $\alpha-\mathrm{BHC}$ & $\beta-\mathrm{BHC}$ & Lindane & $\Upsilon$-BHC & $\begin{array}{l}\text { Chloro } \\
\text { thalonil }\end{array}$ & Heptachlor & Aldrin & $\begin{array}{c}\text { Heptachlor } \\
\text { epoxide }\end{array}$ & $\begin{array}{c}\text { Endosulfan } \\
\text { I }\end{array}$ & Dieldrin & Endrin & $\begin{array}{c}\text { Endosulfan } \\
\text { II }\end{array}$ & P,P ${ }^{\mathrm{I}}-\mathrm{DDD}$ & $\begin{array}{c}\text { Endosulfan } \\
\text { sulphate }\end{array}$ & P,P I-DDT & TOCP \\
\hline CG & - & - & 15.3 & 38.9 & - & - & - & 20.6 & - & - & - & - & - & 10.1 & 16.6 & 101 \\
\hline $\mathrm{CN}$ & - & 6.81 & - & 9.18 & 34.8 & - & 14.7 & 3.62 & - & 89.2 & - & 2.98 & 10.4 & 1.66 & 2.73 & 176 \\
\hline $\mathrm{TZ}$ & - & 2.16 & - & 17.9 & 111 & - & 49.0 & 4.08 & - & - & - & 4.78 & - & 3.05 & 1.29 & 193 \\
\hline ON & - & 1.24 & 1.39 & 3.59 & - & 1.51 & 23.5 & 0.89 & - & - & - & 1.99 & 4.78 & 0.67 & 1.66 & 54.8 \\
\hline HN & - & 9.87 & - & 2.18 & - & - & - & 2.03 & - & - & - & 1.38 & 3.04 & 0.77 & 1.03 & 20.4 \\
\hline \multirow[t]{2}{*}{ Range } & - & $1.24-$ & $1.39-$ & $2.18-$ & $34.8-$ & - & $14.7-$ & $0.89-$ & - & - & - & $1.38-$ & $3.04-$ & $0.67-$ & $1.03-$ & 20.4- \\
\hline & & 9.87 & 15.3 & 38.9 & 111 & - & 49.0 & 20.6 & & & & 4.78 & 10.4 & 10.1 & 16.6 & 193 \\
\hline Mean & - & 5.02 & 8.34 & 14.3 & 72.9 & - & 29.1 & 6.24 & - & - & - & 2.78 & 6.07 & 3.24 & 4.66 & 109 \\
\hline SD & - & 4.16 & 6.71 & 15.0 & 48.2 & - & 20.3 & 8.13 & - & - & - & 1.79 & 4.29 & 3.95 & 6.70 & 74.8 \\
\hline $\mathrm{CV} \%$ & - & 82.9 & 80.4 & 105 & 66.1 & - & 69.7 & 130 & - & - & - & 64.4 & 70.7 & 122 & 144 & 68.6 \\
\hline
\end{tabular}

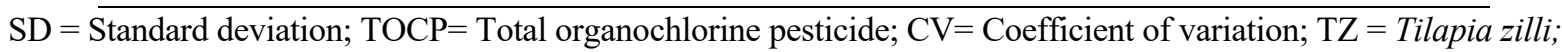

$\mathrm{CG}=$ Clarias gariepinus; $\mathrm{CN}=$ Chrysichthys nigrodigitatus; $\mathrm{HN}=$ Heterotis niloticus; $\mathrm{ON}=$ Oreochromis niloticus. 
Table 6. Enrichment factor (EF) of organochlorine pesticide residues in sediments samples

\begin{tabular}{|c|c|c|c|c|c|c|c|c|c|c|c|c|c|c|c|c|}
\hline Samplecode & $\alpha-\mathrm{BHC}$ & $\beta$-BHC & Lindane & $\Upsilon$-BHC & $\begin{array}{l}\text { Chloro } \\
\text { thalonil }\end{array}$ & Heptachlor & Aldrin & $\begin{array}{c}\text { Heptachlor } \\
\text { epoxide }\end{array}$ & $\begin{array}{c}\text { Endosulfan } \\
\text { I }\end{array}$ & Dieldrin & Endein & $\begin{array}{c}\text { Endosulfan } \\
\text { II }\end{array}$ & $\mathrm{P}, \mathrm{P}^{\mathrm{I}}-\mathrm{DDD}$ & $\begin{array}{c}\text { Endosulfan } \\
\text { sulphate }\end{array}$ & $\mathrm{P}, \mathrm{P}^{\mathrm{I}}$-DDT & TOCP \\
\hline 1 & - & - & 53.5 & 93.0 & - & - & - & 46.2 & - & - & - & - & - & 21.1 & 27.7 & 242 \\
\hline 2 & - & 5.40 & - & 35.8 & 210 & - & 66.4 & 11.7 & - & 111 & - & 6.14 & 25.8 & 2.15 & 5.00 & 479 \\
\hline 3 & - & 40.1 & - & 11.6 & 14.1 & - & 707 & 52.7 & - & - & - & 49.5 & - & 9.51 & 12.9 & 879 \\
\hline 4 & - & 10.3 & 3.05 & 7.84 & - & 90.6 & 27.1 & 2.90 & - & - & - & 4.73 & 14.1 & 1.73 & 2.30 & 165 \\
\hline 5 & - & 41.1 & - & 3.26 & - & - & - & 7.69 & - & - & - & 1.53 & 3.29 & 0.79 & 0.21 & 57.8 \\
\hline \multirow[t]{2}{*}{ Range } & - & $5.50-$ & $3.05-$ & $3.26-$ & 14.1- & - & 27.1- & $2.90-$ & - & - & - & $1.53-$ & 3.29- & 0.79 & $0.21-$ & $57.8-$ \\
\hline & & 41.1 & 53.5 & 93.0 & 210 & - & 707 & 52.7 & & & & 49.5 & 25.8 & 21.1 & 27.7 & 879 \\
\hline Mean & - & 24.2 & 28.3 & 30.3 & 112 & - & 267 & 24.2 & - & - & - & 15.5 & 14.4 & 7.06 & 9.62 & 365 \\
\hline SD & - & 19.0 & 35.7 & 37.2 & 139 & - & 382 & 23.3 & - & - & - & 22.8 & 11.3 & 8.59 & 112 & 327 \\
\hline CV\% & - & 78.5 & 126 & 123 & 124 & - & 143 & 96.3 & - & - & - & 147 & 78.5 & 122 & 116 & 89.6 \\
\hline
\end{tabular}

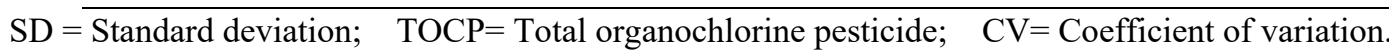

Table 3 showed the mean distribution of OCPs residues in fish parts. The levels of mean OCPs in all the fish samples were higher in the trunk than the head except in Chrysichthys nigrodigitatus. The mean organochlorine pesticide residues in the head ranged from Heterotis niloticus $(1.15 \mu \mathrm{g} / \mathrm{kg})$ to Clarias gariepinus $(54.0 \mu \mathrm{g} / \mathrm{kg})$, whilst the mean OCPs levels in the trunk ranged from Oreochromis niloticus $(0.94 \mu \mathrm{g} / \mathrm{kg})$ to Clarias gariepinus $(107 \mu \mathrm{g} / \mathrm{kg})$. The total mean OCPs residues in the head ranged from Heterotis niloticus $(97.9 \mu \mathrm{g} / \mathrm{kg})$ to Chrysichthys nigrodigitatus $(262 \mu \mathrm{g} / \mathrm{kg})$ whilst the total mean OCPs residues in the trunk ranged from Heterotis niloticus $(105 \mu \mathrm{g} / \mathrm{kg})$ to Clarias gariepinus $(764 \mu \mathrm{g} / \mathrm{kg})$. The total mean organochlorine pesticide residues in the fish head ranged from Heterotis niloticus < Oreochromis niloticus $<$ Tilapia zilli $<$ Clarias gariepinus $<$ Chrysichthys nigrodigitatus whilst the total OCPs in trunk range from Heterotis niloticus $<$ Oreochromis niloticus $<$ Tilapia zilli $<$ Chrysichthys nigrodigitatus $<$ Clarias gariepinus. $\beta$ - BHC was found to be higher in head than the trunk in all the fish samples. Table 4 showed the mean concentration of OCPs residues in the whole fish samples for the five different species. From the results, it can be deduced that all the fish contained measurable levels of all the analysed pesticides residues. The total mean OCPs residue in the whole fish samples ranged from $105 \mu \mathrm{g} / \mathrm{kg}$ in Heterotis niloticus to $490 \mu \mathrm{g} / \mathrm{kg}$ in Clarias gariepinus. The results also showed marked variation in the OCPs burden in the fish samples. This could be attributed to the age of the fish, feeding patterns of the fish, types of the fish samples and variation in ability to concentrate the OCPs in the fish muscle. Chlordane, heptachlor, DDT, DDE and endosulfan detected in these fish samples are known to have endocrine and estrogenic disruptive properties (Soto et al., 1994) which may have an impact on biodiversity of the aquatic life .The detected OCPs are generally persistent, lipophilic and bioaccumulative both in the environment and at each trophic level of the food chain. These contaminants can reach high concentrations through biomagnifications in the tissues of predators including human beings, which are high in food chain resulting in so many health problems such as convulsion in children, incoordination of muscular action, muscular weakness (myasthenia), paralysis, hyperexcitability, damage to the central nervous system (CNS) and cancer.

Comparing the concentration of OCPs residues in the whole fish samples with maximum residue levels (MRLs) in food as prescribed by the European Union and FAO/WHO (Codex Alimentarius), endosulfan I exceeded the MRLs. For Clarias gariepinus, endosulfan I $(66.0 \mu \mathrm{g} / \mathrm{kg})$ was found to be highest. p, p'-DDT was also found to have lowest concentration in Tilapia zilli and Oreochromis niloticus whilst lindane was the lowest in Heterotis niloticus or Chrysichthys nigrodigitatus. The levels of OCPs residues detected in the fish samples from the present study were relatively higher in most cases than the values obtained by Ize-Iyamu et al. (2007) in some fish samples from river Ogba and Ovia in Edo State, Nigeria. Comparing the results with those obtained by Ogunfowokan et al. (2012), $\alpha$-BHC, $\beta$-BHC, $\Upsilon$-BHC, aldrin, $\mathrm{p}, \mathrm{p}^{\prime}-\mathrm{DDD}$ and dieldrin were in similar ranges whilst p,p'-DDT was found to be higher in the present study. The results also showed a trend for the distribution of endosulfan I where concentrations were higher than their metabolites (endosulfan sulphate) whilst the levels of $\mathrm{p}, \mathrm{p}^{\prime}-\mathrm{DDD}$ and dieldrin were higher than the parent compound ( $\mathrm{p}, \mathrm{p}^{\prime}-\mathrm{DDT}$ and aldrin). This suggests that there might not be recent input of DDT in the river. DDT like other organochlorines has been shown to have xenoestrogenic activity, meaning they are chemically similar enough to mimic oestrogens and trigger normal responses in animals. 
Tables 5 showed the bioconcentration factors (BCF) of organochlorine pesticide residues in fish samples in relation to water from Ogbese river. BCF values for most OCPs in the fish samples were greater than 1 . The BCF values ranged from 0.21 (p, p'-DDT) to 222 (chlorothalonil). Table 6 showed the enrichment factor of OCPs in sediment samples. The Enrichment factor (EF) for OCPs in the sediments ranged from 0.21 (p, p'-DDT) to 707 (aldrin). The results showed high accumulation of OCPs in the fish and sediment samples. $\Upsilon$-BHC, heptachlor epoxide, endosulfan sulphate, p, p'-DDT were all accumulated in all the fish samples. Tilapia zilli showed high accumulation of chlorothalonil, aldrin and endosulfan II. $\beta$ - BHC, $\Upsilon$ - BHC, heptachlor epoxide, endosultan II, endosulfan sulphate, aldrin, p, p'-DDD and p, $\mathrm{p}^{1}$-DDT concentrated well in most of the sediment samples as they showed very high EF values. The high EF and BCF values indicated that the OCPs were highly accumulated and biomagnified in the sediments and fish tissues.

\section{Conclusion}

This study shows that the 15 organochlorine pesticides (OCPs) determined were present at detectable levels in most of the samples. All the pesticides determined were found to be contaminants of the fish samples. However, endosulfan I was found to be above the $\mathrm{EU}$ and FAO/WHO residue limits in Clarias gariepinus. This fish is a delicacy particularly among the low income earners in Nigeria. As a result of this, efforts must be made to avoid contamination of our waters and the environment generally because our health status in Nigeria is poor. The concentration of OCPs in the water was low when compared to the concentration in sediments and fish samples, as evidenced of bioaccumulation in sediments and fish samples. The detection of these OCPs in the samples might be due to previous and probably recent use of these pesticides from the agricultural areas which are the major sources of these contaminants in the river. The OCPs residues may have direct or indirect effects on the build-up environment and the health of the people especially people living around the area. The Federal Environmental Protection Agency had published regulations on the control of various types of pesticides within the Nigerian environment. Therefore, there is need to monitor and enforce the existing laws on the production, transportation and use of banned pesticides as stipulated by the Federal Ministry of Environment in Nigeria. Other rivers and food samples should be studied in details as related to monitoring, assessment, distributional trends, sources identication and ecotoxicological effects of persistent organochlorine pesticides.

\section{Acknowledgement}

The authors wish to acknowledge the technical assistance rendered by the Chemical Laboratory of the National Food and Drug Administration and Control, Oshodi, Nigeria.

\section{References}

Adeyemi, D., Anyakora, C., Ukpo, G., Adedayo, A., \& Darko, G. (2011). Evaluation of the levels of organochlorine pesticide residues in water samples of Lagos Lagoon using solid phase extraction method. Journal of Environmental Chemistry and Ecotoxicology, 3(6), 160-166. http://dx.doi.org/10.5897/JECE 2014.0337

Afful, S., Arim, A. K., \& Sertor-Armah, Y. (2010). Spectrum of organochlorine pesticide residues in fish samples from Dense basin. Research Journal of Environmental Earth Sciences, 2(3), 133-138.

Ajayi, S. O., \& Osibanjo, O. (1981). Pollution studies on Nigerian rivers: water quality of some Nigerian rivers. Environmental Pollution, 2, 87-95. http://dx.doi.org/1080/02772240802614564

Akinnifesi, T. A., Asubiojo, O. 1., \& Amusan, A. A. (2006). Effects of fungicide residues on the physicochemical characteristics of soils of a major cocoa-producing area of Nigeria. Science and Total Environment, 366(2-3), 876-879.

ATSDR Agency of Toxic Substances and Disease Registry. (2002). Toxicological profile for aldrin and dieldrin. Atlanta. GA, US department of Health and Human Services Public Health Service (p. 116).

Ennacer, S., Gandaoura, N., \& Driss, R. (2008). Distribution of Polychlorinated biphenyls and organochlorine pesticides in human breast milk from various locations in Tunisia. Levels of contamination, influencing factor and infant risk assessment. Environmental Research, 108, 86-93.

European Union Commission Regulation (EC). (2005). No 396/2005 of the European parliament and of the council of 23 February 2005 on maximum residue levels of pesticides in or on food and feed of plant and animal origin and amending council Directive 91/414/ E-text with EEA relevance.

FAO/WHO Food standards (ND). Codex alimentarius, Maximum Residue Limits of Pesticides in Food. Retrieved from http://www.codexalimentarius.net/mrls/pesticides/jsp/pest-q-e.jsp 
Federal Environmental Protection Agency now Federal Ministry of Environment. (1991). Guidelines and standards for environmental pollution control in Nigeria. Retrieved from www.placng.org/new/laws/F10

Hong, H., Chen, W., Xu, L., Wang, X., \& Zhang, L. (1999). Distribution and fate of organochlorine pollutants in the Pearl River estuary. Marine pollution Bulletin, 39, 376-382. http://dx.doi.org/10.1016/S0025-326X(99)00081-8

Idowu, G. A., Aiyesanmi, A. F., \& Owolabi, B. J. (2013). Organochlorine pesticide residue levels in river water and sediment from cocoa producing area of Ondo State central senatorial district, Nigeria. Journal of Environmental Chemistry and Ecotoxicology, 5(9), 242-249.

Ize-Iyamu, O. K, Asia, I. O., \& Egwakhide, P. A. (2007). Concentration of residues from organochlorine pesticide in water and fish from some rivers in Edo State, Nigeria. International Journal of Physical Sciences, 2(9), 237-241.

Lars, H. (2000). Environmental exposure to persistent organohalogen and health risks. In M. Lennart (Ed.), Environ Med: 12. Retrieved from www.envimed.com

Mmualefe, L. C., Torto, N., Huntsman-Mapila, P., \& Mbongwe, B. (2009). Headspace solid phase microextraction in the determination of pesticides in water samples from the Okavangho Delta with GC-ECD and time of flight mass spectrometry. Microchemical Journal, 91, 239-244.

Nizzetto, L., Pastore, C., Liu, X., Camporini, P., Stroppiana, D., Herbert, B., ... Guardo, A. D. (2008). Accumulation parameters and seasonal trends for PCBs in Temperate and Boreal forest plant species. Environmental Science and Technology, 42, 5911-5916.

Ogunfowokan, A. O., Oyekunle, J. A. O., Torto, N., \& Akanni, M. S. (2012). A study on persistent organochlorine pesticide residues in fish tissues and water from an agricultural fish pond. Emirate Journal of Food Agriculture, 24(2), 165-184.

Okoya, A. O., Ogunfowokan, A. O., Asubiojo, O. I., \& Nelson, T. (2013). Organochlorine pesticide residues in sediment and waters from cocoa producing areas of Ondo State, Southwestern, Nigeria. Soil Science, 1-12. http://dx.doi.org/10.1155/2013/131647

Osibanjo, O., \& Bamgbose, O. (1990). Chlorinated hydrocarbons in marine fish and shellfish of Nigeria. Marine Pollution Bulletin, 21, 581-586. http://dx.doi.org/10.1016/0025-326X(90)90607-A

Raposo Jr, L. J., \& Nilva, R. P. (2007). Determination of organochlorine pesticides in ground water samples using solid-phase microextraction by gas chromatograph electron capture detection. Talanta, 72, 1833-1841.

Shukla, G., Kumar, A., Bhanti, M., Joseph, P. E., \& Taneja, A. (2006). Organochlorine pesticide contamination of ground water in the city of Hyderabad. Environment International, 32, 244-247. http://dx.doi.org/10. 1016/j.envint.2005.08.027

Simonich, S. L., \& Hites, R. A. (1995). Organic pollutant accumulation in vegetation. Environmental Science Technology, 29, 2905-2914.

Soto, A. M., Chung, K. L., \& Sonnenshien, C. (1994). The pesticides endosulfan, toxaphene, and dieldrin have estrogenic effects on human estrongen-sensitive cells. Environmental Health Perspective, 102(1), 380-385.

US Environmental Protection Agency (US EPA). (2000). SW-846 Test methods for evaluating solids waste (3rd ed., Update IVB. Chapter 4). Organic analyte US EPA 2000, Washington DC, USA.

US Environmental Protection Agency (US EPA). (2007). Method 3510 (Revision C, 2007). Washington DC, USA.

Zhang, G., Min, Y. S., Mai, B. X., Sheng, G. Y., Fu, J. M., \& Wang, Z. S. (1999). Time trend of BHCs and DDTs in a sedimentary core in Macao estuary, Southern China. Marine Pollution Bulletin, 39, 326-330.

\section{Copyrights}

Copyright for this article is retained by the author(s), with first publication rights granted to the journal.

This is an open-access article distributed under the terms and conditions of the Creative Commons Attribution license (http://creativecommons.org/licenses/by/3.0/). 